\title{
Intermédialités
}

Histoire et théorie des arts, des lettres et des techniques

Intermediality

History and Theory of the Arts, Literature and Technologies

\section{Introduction. Rendering (Time)}

\section{Vincent Bouchard et Ira Wagman}

Numéro 33, printemps 2019

restituer (le temps)

rendering (time)

URI : https://id.erudit.org/iderudit/1065012ar

DOI : https://doi.org/10.7202/1065012ar

Aller au sommaire du numéro

Éditeur(s)

Revue intermédialités

ISSN

1920-3136 (numérique)

Découvrir la revue

Citer ce document

Bouchard, V. \& Wagman, I. (2019). Introduction. Rendering (Time)

Intermédialités / Intermediality, (33). https://doi.org/10.7202/1065012ar d'utilisation que vous pouvez consulter en ligne.

https://apropos.erudit.org/fr/usagers/politique-dutilisation/ 


\title{
Rendering (Time) ${ }^{1}$
}

\author{
VINCENT BOUCHARD \\ IRA WAGMAN
}

T

his special issue of Intermédialités/Intermediality considers the relationship between media, time, and forms of cultural and artistic expression. With the contributions to this issue, we aim to engage closely with an exciting and longstanding research theme that mixes philosophy and media and film studies with work from history, geography, women and gender studies, and the expansive field of environment and ecological studies. ${ }^{2}$ The continued interest in the question of time

\footnotetext{
I The guest editors of this issue would like to thank the journal, the editorial board, the external reviewers, and the journal's copyeditors.

${ }^{2}$ See Ernst Cassirer, "The Human World of Space and Time," An Essay on Man: An Introduction to the Philosophy of Human Culture, New Haven, Connecticut, Yale University Press, 1944, p. 42-55; E. P. Thompson, “Time, Work-Discipline and Industrial Capitalism,” Past and Present, no. 38, 1967, p. 56-97, https://www.jstor.org/stable/649749 (accessed 6 July 2019); Johannes Fabian, Time and the Other: How Anthropology Makes Its Object, New York, Columbia University Press, 1983; Lauren Berlant, "Slow Death, (Sovereignty, Obesity, Lateral Agency)," Critical Inquiry, vol. 33, no. 4, summer 2007, p. 754-780, https://www.jstor.org/stable/Io.I086/521568 (accessed 6 July 2019); Stephen Kern, The Culture of Time and Space, 1880-1918, Cambridge, Massachusetts, Harvard University Press, 1983; Robert Hassan, "Timescapes of the Network Society," Fast Capitalism, vol. I, no. I, 2005, http://www.uta.edu/huma/agger/fastcapitalism/I_I/hassan.html (accessed 6July 20r9); Paul Virilio, Speed and Politics, Cambridge, Massachusetts, MIT Press, 2006; Dipesh Chakrabarty, "The Climate of History: Four Theses," Critical Inquiry, vol.35, no. 2, winter 2009, p. 197-222, https://www.jstor.org/stable/10.I086/596640 (accessed 6July 2019); Sarah Sharma, In the Meantime: Temporality and Cultural Politics, Durham, North Carolina, Duke University Press, 2014; Jonathan Crary, 24/7: Late Capitalism and the Ends of Sleep, London, Verso, 2015; Judy Wajcman, Pressed for Time: The Acceleration of Life in Digital Capitalism, Chicago, University of Chicago Press, 20I5; Will Straw and Luc Gwiazdzinski, "Introduction: Habiter (la nuit)/inhabiting (the night)," Intermédialités/Intermediality, no. 26, fall 2015, https://id.erudit.org/iderudit/I0373I2ar (accessed 6 July 2019); Paul Huebener, Susie O'Brien, Tony Porter, Liam Stockdale, Yanqiu Rachel Zhou(eds.), Time Globalization and the Human Experience: Interdisciplinary Explorations, London, Routledge, 2016; Melissa Gregg, Counterproductive: Time Management in the Knowledge Economy, Durham, North Carolina, Duke University Press, 2018.
} 
mediations is in large part due to the incredible ways, that our experience of time has been transformed by major meta-phenomena, from electrification and international air travel, to globalization and climate change, by technological innovations that have reorganized our understanding of time in important ways, and by the appreciation that experience is structured by politics, capital, and other hegemonic expressions of power.

In this issue, we start from a basic position: All forms of mediated communication can be understood in terms of space and time. With an attention to the temporal components of this relationship, we can think of these things in the banal sense: we rely on numerous media forms to tell us what time it is, and various aspects of our public life are intended to remind us about things like life and death, the beginning and end of things. Innovations such as national broadcasting systems and YouTube make it possible for people to experience events simultaneously (or close to it) across geographical locations. ${ }^{3}$ Many devices, from cameras to computers, are able to freeze time, to play it in reverse, or to take images from different time periods and "photoshop" them together. Genres of cultural content, from year-end lists to notions of "prime time," carve up and recalculate time according to commercial purposes. We frequently talk of life being "speeded up" because of the power of digital technologies, a perception that runs alongside the development of communication technologies in the modern era. Developments such as the recent economic crisis imply a temporal break, a time that implies rethinking and transformation. A discussion about the "newness" of media technologies is itself a discussion about time, about what came before our latest innovations, what may come after, or about how history repeats itself. ${ }^{4}$ How we have come to conceive of a variety of developments associated with digital culture is also intimately tied up with ideas about time, whether in terms of 24 -hour news channels or "real-time" information. But we can also consider the temporal and environmental dynamics of processes of consumption and commodification; most technological devices are built to be obsolete, to be short-term affairs before moving on to the newest thing. ${ }^{5}$

${ }^{3}$ One of the most famous examples linking nation-building to time is found in Benedict Anderson, "Cultural Roots," Imagined Communities, New York, Verso, 1983, p. 9-37.

${ }^{4}$ An interesting treatment of the literature on "new" media history is Benjamin J. Peters, "And Lead Us Not into Thinking the New is New: A Bibliographic Case for New Media History,” New Media and Society, vol. II, no. I-2, 2010, p.13-30, https://journals.sagepub.com/doi/abs/Io.II77/I461444808099572 (accessed 6 July 2019).

s See Jonathan Sterne, "Out With the Trash: On the Future of New Technologies," Charles Acland(ed.), Residual Media, Minneapolis, Minnesota, University of Minnesota Press, 2007, p. 16-3I; Sabine LeBel "Fast Machines, Slow Violence: ICTs, Planned Obsolescence, and E-waste,” Globalizations, vol. I3, no. 3, June 2015, p. 300-309. 
What lies behind these different characterizations is the idea that time is rendered both by and through media technologies. From photography to cinema, from video art to memes, we can understand the temporal dimensions of mediated expression. Media represent (or mis-represent) and organize (and dis-organize), they store and disseminate, they facilitate control on the one hand and encourage movement on the other. Through these efforts, media serve a transformative purpose; through acts of representation and manipulation, one can appreciate the forces that structure and dictate the times of our lives.

At the same time, audiovisual technologies alter our media practices and our understanding of aesthetic concepts. Moreover, beyond issues of representation, all cultural practices related to temporal media represent an epistemological shift in our conceptualizations of modern values, starting with how we configure time. In this respect, the practices explored in this issue font époque, ${ }^{6}$ they form specific configurations of media which, as apparatuses, structure events in such a way as to alter both our cognitive processes and our modern views of the world. Through their ability to record, to remix and replay, and to modify one's performance, temporal media have incredible potential to alter our consciousness of the world around us, and structure how we fundamentally understand, reorganize and memorize those perceptions. As a result, we believe it is productive to explore in some detail the ways these temporal media are an essential part of our aesthetic experience of different art forms, which can be understood along temporal lines: from montage and "cut-up" methods, from vinyl, film, photography, or video, to the televisual scheduling experience of "flow" or the digital mix.

Let us consider this question in some detail.

One of the more prominent aspects of the relationship between media and temporality that is of interest to journalists, sociologists, neuroscientists, and philosophers alike has been a concern with the ways audiovisual recording and broadcasting techniques imprint messages and ideas onto the brain. This becomes salient around ideas related to memory. In On the Phenomenology of the Consciousness

\footnotetext{
${ }^{6}$ Jean-Louis Déotte, L'époque des appareils, Paris, Éditions Lignes \& Manifestes / Léo Scheer, 2004.
} 
of Internal Time ${ }^{7}$ Edmund Husserl considers that our knowledge of things comes from our ability to bring together several dimensions of memory, be they mnemic and unconscious traces of our perceptions that orient our apprehension (moment lived) or our consciously solicited memories that preserve their unity in time. Husserl differentiates the primary retentions generated by any act of consciousness from those that our consciousness targets as a reminder of the past (secondary retention).

In the third volume of Technics and Time, ${ }^{8}$ Bernard Stiegler emphasizes the specific tertiary retentions that are "temporal objects" and ascribes them with the power to change our memory capabilities. There are, as a result, a number of different theories that attempt to understand the impact of temporal objects on the ways in which we make a selection among our primary retentions in order to constitute a memory (secondary retention), but also to understand the influence of temporal objects on the set of selection criteria that we use-we can think of the notion of "wanting horizon" (Erwartungshorizont) and Wirkung in the work of Hans Robert Jauss. ${ }^{9}$

It therefore is necessary to further expand our vocabulary for thinking about how to question media's capacity to record and store, to offer experiences of simultaneity and delay, and to communicate presence, nostalgia, and loss to our cultural and cognitive structures. This effort requires further engagement with theoretical traditions from a number of established disciplines: the clinical study of memory pathologies, the observation of user behaviour, and an analysis of the works covered by these questions. This effort must also consider the developments brought forth by digital technologies and the ways in which those technologies impact upon how we remember-and what we remember. It is thus the goal of this issue of Intermédialités/Intermediality to provide insights on these questions and to consider that various kinds of artistic practices, from montage to flashbacks and from collage to remixing, have both a temporal component and a mediational one. Setting

7 Edmund Husserl, On the Phenomenology of the Consciousness of Time, transl. from German by John Barnett Brough, Dordrecht, The Netherlands: Kluwer Academic Publishers, I991.

${ }^{8}$ Bernard Stiegler, Technics and Time, 3: Cinematic Time and the Question of Malaise, transl. from French by Stephen Barker, Stanford, California, Stanford University Press, 2010 [200I].

9 Hans Robert Jauss, "Literary History as a Challenge to Literary Theory," New Literary History, vol. 2, no. I, fall 1970, p. 7-37. See David Wills, Dorsality: Thinking Back through Technology and Politics, Minneapolis, Minnesota, University of Minnesota Press, 20o8; Niko Besnier, Gossip and the Everyday Production of Politics, Honolulu, Hawai'i, University of Hawai'i Press, 2009. 
questions of artistic practice alongside approaches drawn from media studies, visual culture studies, performance studies, art history, sound studies, and popular music studies, this special issue considers the interaction between creative expression and technological innovation.

Such associations are themselves reminders of the longstanding interest in understanding the relationship between mediated experience and changes of behaviour. The history of media theories is a history of attempting to account for the effects those media have on what we do and think. Whether we consider the more direct effects associated with "hypodermic needle" theories of media consumption or the more "active audience" theories we associate with fields of research ranging from cultural studies to critical feminist accounts of mediated experience, the relationship between media's temporal capacities and its behavioural effects are commonly paired together. ${ }^{\text {I }}$

Moving away from the more perceptual associations between technologies (and technics) of time, we can also say that one of the more powerful functions of media technologies is their capacity to manipulate time. From the foundational work of Harold Innis we learn about the ways that media technologies may have "biases" towards time or space that affect how societies are organized. ${ }^{I I}$ We also know about how electrification, from telegraph to television, dematerializes human communication and distributes it across physical spaces to give people the experience of connection. ${ }^{\mathrm{I} 2}$ Our sense of history is based largely on the ability of different media forms-paper, vinyl, film, videocassette, and now "clouds" - to hold onto the past. We now watch news unfold on channels that operate on a 24-hour, 7-day cycle. In the past we have used the experience of watching the Olympics, or a Moon landing, or famously, of reading the newspapers or listening to radio, as having the effect of bringing nations together "in time," if not in the sense of physical togetherness.

Io For a few illustrative examples, see Hadley Cantril, The Invasion from Mars: A Study in the Psychology of Panic, Princeton, New Jersey, Princeton University Press, 1940; Ien Ang, Desperately Seeking the Audience, New York, Routledge, 1991; Stuart Hall, "Encoding and Decoding in the Television Discourse," in Essays. Selections, Durham, North Carolina, Duke University Press, 2019; Liesbet van Zoonen, Feminist Media Studies, London, Sage, 1994; Rosalind Gill, Gender and the Media, Cambridge, UK, Polity, 2007; Michel Foucault, L'ordre du discours. Leçon inaugurale au Collège de France prononcée le 2 décembre 1970, Paris, Gallimard, 1971; Michel de Certeau, L invention du quotidien, Paris, Gallimard, 1980.

${ }^{11}$ Harold Innis, The Bias of Communication, Toronto, University of Toronto Press, 1951.

${ }^{12}$ Marshall McLuhan, Understanding Media: The Extensions of Man, New York, New American Library, coll. "Signet Book," 1964; James W. Carey, "Technology and Ideology: The Case of the Telegraph," Communication as Culture, Boston, Unwin Hyman, 1989, p. $201-230$. 
Another important component is the tremendous capacity of digital technologies to exteriorize individual and collective memory. The ubiquity of the digital and of smartphones allows for the experience of being "always on.” We react to things in the world almost instantaneously with every click and tweet. The Internet's incredible capacity for storage allows various aspects of the past to be recycled and redistributed again and again, for the nostalgic and the "retro" to sit alongside things that are new, or repurposed, or remixed.

Equally important to consider are the various ways in which the timerendering characteristics of media technologies serve as valuable tools for artistic expression. Of particular importance to this issue is how they can serve a narrative purpose in the development of storylines or even how their capacity may serve as the primary inspiration for various kinds of artistic expression. We can think of films like Dial M for Murder (Alfred Hitchcock, 1954) as illustrating the terror that the idea of mysterious, disembodied voices travelling through the air in telephone conversations can cause. Similarly, in movies like WarGames (John Badham, 1983) or 200I: A Space Odyssey (Stanley Kubrick, 1968) the powers of computers are highlighted to expose the social concern about the unfettered power of machinesand the humans' ability to stop them. The role of text messaging in the Netflix series Master of None (Aziz Ansari, 2015-2017), allows audiences to see character reactions when messages from people from far away appear on the screen. Finally, there is the use of the social networking platform Facebook in the television show God Friended Me (Steven Lilien and Bryan Wynbrandt, 2018-), where the platform serves as the medium through which the divine communicates with an avowed atheist. In this sense we can say that intermediality is about the way that different media forms work together to render and manipulate time and convert those characteristics into powerful narrative devices as well as to provide "points of view" that go beyond human capacities to see, hear, or feel.

With these various connotations of the relationship between mediality and temporality, we can identify a number of important analytical concepts. Media's capacity for representation raises questions about authenticity or fakery. Questions about control over media's temporal powers are also significant in this regard. The material forms that media take draw us into issues having to do with obsolescence or the recycling of forms. Ideas of newness are also coupled with ideas of repetition, both at the level of content and format. For example, the lack of historical perspective leads users to think about their time period as the first to experiment with specific challenges (in aesthetic terms, but also at the level of technical adaptation or social 
appropriation). Aside from this impression of constant novelty, the contradictory impression of transparency and bypermediacy leads us to forget about the structuring impact of the medium. ${ }^{\mathrm{I3}}$

This issue of Intermédialités/Intermediality brings together texts on the various impacts that modes of medial and intermedial communication have upon our memory, modes of perception, cultural structures, and our ability to represent and manipulate the world around us. Our aim is to critically challenge attempts that seek to homogenize media as being all and the same and to develop a common conceptual vocabulary.

Antoine Constantin Caille’s article "Temporaliser la photographie : Marker, Varda, Wenders-Salgado” poses a series of fundamental questions, which constitute a form of introduction to the complex topics explored in this issue, based on a close analysis of three films: Si j'avais quatre dromadaires by Chris Marker (1966), Ulysse by Agnès Varda (1982), and Salt of the Earth by Wim Wenders and Juliano Ribeiro Salgado (20I4). Caille's analysis focuses on the concept of "time rendering" from a qualitative point of view and the distinction between informative and artistic restitution. Despite the fact that photograms are differentiated from film, Caille demonstrates how the films in question control how long specific photographs are exposed to the viewer. In these films, the medium of film operates as a form of temporalization by showing photographs through their insertion into the temporal continuity of the film, interacting with other cinematographic elements such as the voice-over, which provides context about the photograph itself. Thus, time rendering as chronological construction and localisation explains the context, the circumstances, and the story behind it. In doing so, this article opposes the dreamlike creation of temporalities and contextualization, restitution of context, and free interpretation, which creates a distance from the represented reality.

The interplay between recorded and live performances is a prominent theme in two papers for this collection. Alanna Thain writes that a discussion of the remixing of archival materials requires an ecosophical approach, one that connects creative practices to modes of world-making. The generative capacity of remixing to repurpose and remodulate meaning offers to extend cinematic texts beyond the

${ }^{13}$ Jay David Bolter and Richard Grusin, Remediation: Understanding New Media, Cambridge, Massachusetts, MIT Press, 1999. 
frame. In her article Thain focuses on two case studies: the Nunavut-based artist Tanya Tagaq's live remix performance of Robert Flaherty's 1922 film Nanook of the North (2012-) and the remix of Alfred Hitchcock's 1958 film Vertigo in Guy Maddin, Galen and Evan Johnson's film The Green Fog (20I7). Through these case studies, she identifies practices of chronic collage, which enter these historical and archival texts into new relations of meaning and, in the process, raise important questions about the nature of embodied memory.

Lowell Gasoi considers the intermedial nature of theatrical performance, noting the increasingly present role of the video designer as a now common part of the production crew. Gasoi explores how video is used for a range of purposes within a theatrical performance and how it has come to form a crucial component of theatre, from stage design to the presence of digital characters, in order to supplement the live aspects of the performance. Reflecting on his own experience using video for a performance of Daniel MacIvor's play Never Swim Alone (I99I) and engaging with literature from performance studies to media theory, Gasoi outlines the ways that media serve a narrative purpose as the repository for the memories of different characters. It is that relationship between media and memory that is part of Gasoi's call to consider the connection between the editorial choices made in video presentation and the ethical implications of those choices in order to better understand the performative aspects of media forms and the technological transformations of live theatre.

In the article "Du document aux flux : sites et temporalité(s) de quelques œuvres d'art," Suzanne Paquet explores the links between artistic propositions and sociocultural networks. Borrowing the concept of "chronogéographie" from Land Art and géographie de l'art, the author examines Robert Smithson's Spiral Jetty and Nancy Holt's Sun Tunnels. These photographs, as active or performative forms of art, provoke a series of displacements: metaphorical, geographical, and temporal. Through an analysis of photography as a form of prospective regard, the author draws a comparison between the influence of mechanist representations of time and its evolution during the electric age.

Sandrine Siméon's article "Film-théâtre, intermédialité et nouveaux enjeux esthétiques" questions the complex relations between live performances and audiovisual recordings due to an increased presence of "film-theatre" that offers new possibilities for reflection on the phenomena of hybridization between cinema and theatre. Defining a form of "inter-cannibalism" between the two arts, the author questions the relation between theatrical staging and film rhetoric and the crossing of 
the media border. Siméon examines the filming of theatrical representations and explores the impact of a live performance on audiovisual recording. She concludes with a form of hybrid enunciation, a "meta-theatricalness," combining an anchor in the present time through a synchronistic recording of performance, image, sound, and space and the status of archive, allowing both the analysis of the creative process and the constitution of a precious memory.

Andréane Morin-Simard's “Mémoire et affect dans les recontextualisations multimédiatiques de chansons populaires: autour de 'Fortunate Son' de CCR (1969)" looks at the influence of music, specifically the song Fortunate Son (1969) by Credence Clearwater Revival, on playing and watching audiovisual games. MorinSimard's article focuses on the song's presences in the video game Call of Duty: Black Ops (Treyarch, 20I0), analyzes the revival of this popular musical theme, and shows how music impacts both the design of the game and the cultural context of the fictional world where the action takes place. The relationship between the music and the world of the game similarly impacts the memorization process of the player who is actively experiencing the game in the present. Thus, the author describes the influence of a temporal object on our perception of things, altering a memory or constructing a new point of view: how the media staging of a musical excerpt affects the perceptual and interpretative activities of the listener.

Anais Nony's contribution to this collection considers artistic techniques as instruments for the enabling of what she calls "moving image memory." To illustrate this concept, she explores the relationship between memory and video present in the work of artist Thierry Kuntzel's The Waves (2003). She posits Kuntzel's notion of the "videogram" as a space between culture and technique and as a form of prosthetic memory, something showing appearance and disappearance. She shows how digital conditions allow for the experience of time as always "in flight" and as symbolizing the means by which those technologies facilitate new kinds of connections.

We are delighted to feature two articles examining the avant-garde musician William Basinski's The Disintegration Loops (2002-2003) as a way to theorize the relationship between media and the rendering of time. Basinski's work is a fouralbum series featuring musical fragments pulled from a radio station that were played in loops that gradually degraded every time they passed through the tape spindle as the music was being digitized. Shortly after Basinski digitized these loops, New York City was attacked on September II and the images on the album cover along with the music's melancholic and contemplative tone came to serve as a powerful memorial to the attacks. Basinski's Loops serve as a good example of how the dynamic between 
analog and digital recording technologies have also inspired meditations on the relationship between forms of mediated memory and the ways we appreciate time.

For Jakko Kemper, The Disintegration Loops are an invitation to consider the ways in which digital technologies modify the experience of time-consciousness. Drawing on concepts from Derrida (such as spacing and autoimmunity) and Martin Hagglund's concept of chrono-libido, Kemper suggests that Basinski's sonic inscription of the passing of time and of the material characteristics of decay offers a counterweight to the dominant forms of mediated experience. He shows how Basinski's Loops provide an alternative to the phenomenological experience of time that is linked inextricably to media technologies, which document, reshuffle, and present time according to non-human logics. In short, it is an attempt to use analog media processes to imagine a world that is not determined by digital media.

In David Jackson's account, it is ideas of repetition and feedback that inspire reflection on Basinski's temporal rendering. In an account bringing together historical work on avant-garde music with the rich literature from sound studies, Jackson locates Loops within a longer history of time manipulation by magnetic tape, an account that goes from the "turntablism" of John Cage, the tape-splice experimentalism of William S. Burroughs, to the music of Steve Reich and Miles Davis. Here Jackson considers the ways that looping is used to order everyday flows of consciousness and marry interactions between the social and the machinic. $\mathrm{He}$ then turns to an account of the poetics of Basinski's compositions to conclude that looping represents Basinski's attempt to keep the possibilities of sound always in a state of potential becoming and development. Through a close reading of elements from Basinski's other recordings, Jackson concludes that his word extends a concurrence between the human experience of duration with the technological understanding of industrial time. These two reflections are followed by an interview with Basinski, which was conducted by André Habib assisted by Charlotte BradySavignac. 


\section{Rendering (Time)}

VINCENT BOUCHARD, INDIANA UNIVERSITY

IRa Wagman, Carleton University

\section{BIOGRAPHICAL NOTES}

Vincent Bouchard is Associate Professor of Francophone Studies at Indiana University-Bloomington. He currently works on the various forms of cinematographic practices developed in West Africa since the 196os, including the conditions experienced by early filmmakers, the popular reception of films, and the practices of educational and colonial screenings and their impact on African cinema. His recent works include the book Pour un cinéma léger et synchrone à Montréal! (Presses universitaires du Septentrion, 20I2) and the articles "Cinomade and the fight against the HIV/AIDS pandemic in Burkina Faso" (2017) and "European Design of Propaganda When Confronted with Colonial African Realities” (2019).

Ira Wagman is Associate Professor of Communication and Media Studies at the School of Journalism and Communication at Carleton University in Ottawa. He researches and writes in the areas of media history, communication theory, and the ethics of media technologies. His current research explores the role of the apology in digital culture, a study of the influence of the Catholic Church on the development of television in Quebec in the 1950s, and a study of the relationship between media theory and notions of verticality. 